\title{
Accumulation of Cadmium and Cobalt by Saccharomyces cerevisiae
}

\author{
By P. R. NORRIS* \\ Department of Microbiology, Queen Elizabeth College, London W8 $7 \mathrm{AH}$ \\ AND D. P. KELLY \\ Department of Environmental Sciences, University of Warwick, Coventry $\mathrm{CV}_{4} 7 \mathrm{AL}$
}

(Received I3 December 1976)

\begin{abstract}
SUMMARY
Saccharomyces cerevisiae accumulated $\mathrm{Co}^{2+}$ and $\mathrm{Cd}^{2+}$ by two processes: the first, which was metabolism-independent, was presumably cation binding to the cell surface; this was followed by metabolism-dependent, progressive uptake of relatively large amounts of the cations. Two $\mathrm{K}^{+}$ions were released for each $\mathrm{Co}^{2+}$ ion taken up in freshly prepared cell suspensions whereas extensive loss of cell $\mathrm{K}^{+}$ followed the uptake of $\mathrm{Cd}^{2+} . \mathrm{Co}^{2+}$ and $\mathrm{Cd}^{2+}$ appeared to be accumulated via a general cation uptake system, with limited specificity related to the ionic radii of the cations.
\end{abstract}

\section{INTRODUCTION}

During the last decade, the study of metal accumulation by various organisms has been facilitated by the use of isotopes and atomic absorption spectrophotometry for the selective measurement of elements. During the same period, increased concern has developed over the ecological effects of toxic metal pollutants and particularly over the release of cadmium into the environment (Nilsson, 1970; Nordberg, 1974). The absence of cadmium from a useful review of the effects of heavy metals on fungal cells (Ross, 1975) reflects the paucity of information on interactions of micro-organisms and this potentially hazardous metal.

Metal accumulation by micro-organisms generally comprises two phases: a rapid binding of cations to negatively-charged groups on the cell surface, and progressive, usually metabolism-dependent, intracellular cation uptake. Both phases of cation accumulation by yeasts have been described in studies primarily concerned with essentially non-toxic cations (Rothstein \& Hayes, 1956; Rothstein et al., 1958; Fuhrmann \& Rothstein, 1968; Ponta \& Broda, 1970; Failla, Benedict \& Weinberg, 1976).

Energy-dependent uptake of several divalent cations by Saccharomyces cerevisiae has been described with an affinity series of $\mathrm{Mg}, \mathrm{Co}, \mathrm{Zn}>\mathrm{Mn}>\mathrm{Ni}>\mathrm{Ca}>\mathrm{Sr}$ (Rothstein et al., 1958; Fuhrmann \& Rothstein, 1968), and a similar affinity series for divalent cation activation of yeast plasma membrane ATPase has indicated that the enzyme activity may be related to cation transport in whole cells (Fuhrmann, Wehrli \& Boehm, 1974). In contrast to this apparently general cation uptake system, $\mathrm{Zn}^{2+}$ uptake by Candida utilis was effected by a specific, energy-dependent pathway, unaffected by several other cations but inhibited by $\mathrm{Cd}^{2+}$ (Failla et al., 1976).

* Present address: Department of Environmental Sciences, University of Warwick, Coventry CV4 7AL. 
The accumulation of $\mathrm{Cd}^{2+}$ by $S$. cerevisiae is described in this paper and compared with the accumulation of $\mathrm{Co}^{2+}$, for which energy-dependent uptake by $S$. cerevisiae has been described previously (Fuhrmann \& Rothstein, 1968).

\section{METHODS}

Organism and culture conditions. Saccharomyces cerevisiae (NCYC431) was maintained at $4{ }^{\circ} \mathrm{C}$ on $2 \%(\mathrm{w} / \mathrm{v})$ nutrient agar (Oxoid) containing $0 \cdot \mathrm{I} \%(\mathrm{w} / \mathrm{v})$ yeast extract (Oxoid) and $1 \%(w / v)$ glucose. For metal cation accumulation experiments, the organism was grown at $30{ }^{\circ} \mathrm{C}$ at $\mathrm{pH} 6.8$ in medium containing $\left(\mathrm{g}^{-1}\right): \mathrm{KH}_{2} \mathrm{PO}_{4}, 2 \cdot 72 ; \mathrm{K}_{2} \mathrm{HPO}_{4}, 5 \cdot 22$; $\left(\mathrm{NH}_{4}\right)_{2} \mathrm{SO}_{4}, \mathrm{I} \cdot 98 ; \mathrm{MgSO}_{4} \cdot 7 \mathrm{H}_{2} \mathrm{O}, 0.12 ; \mathrm{FeSO}_{4} \cdot 7 \mathrm{H}_{2} \mathrm{O}$, 0.0022; D-glucose, 10.0; and yeast extract, $\mathrm{I} \cdot 0$. Flasks $(2 \mathrm{l})$ containing $400 \mathrm{ml}$ medium were shaken at $200 \mathrm{rev} . \mathrm{min}^{-1}$ on an orbital shaker. Growth was followed turbidimetrically, using an EEL colorimeter (green filter, peak transmission $540 \mathrm{~nm}$ ), and by culture dry weight measurements, after centrifuging $4 \mathrm{ml}$ samples, washing with $4 \mathrm{ml}$ distilled water and drying the cell pellets at $105^{\circ} \mathrm{C}$ for $\mathrm{i} 8 \mathrm{~h}$.

Preparation of cell suspensions. Cultures were harvested during exponential growth (culture dry wt 0.75 to $\mathrm{I} .25 \mathrm{mg} \mathrm{ml}^{-1}$ ), washed twice by resuspension in distilled water, and resuspended in 5 mM-piperazine- $N, N^{\prime}$-bis(2-ethanesulphonic acid) (PIPES; Good et al., 1966) adjusted to $\mathrm{pH} 6.5$ with tetramethylammonium hydroxide. This buffer has negligible metal-chelating properties. Suspensions were adjusted by dilution with PIPES buffer to approximately $0.4 \mathrm{mg}$ dry $\mathrm{wt} \mathrm{ml}^{-1}$ by reference to a previously determined extinction-cell dry weight correlation for suspensions of yeast in buffer.

Metal cation accumulation assay. Yeast suspensions $(48.5 \mathrm{ml})$ were shaken in $250 \mathrm{ml}$ Erlenmeyer flasks at $200 \mathrm{rev} . \mathrm{min}^{-1}$ in an orbital shaker at $25^{\circ} \mathrm{C}$. Distilled water $(0.5 \mathrm{ml})$ or, where required, I M-glucose $(0.5 \mathrm{ml})$ was added $10 \mathrm{~min}$ before addition of $\mathrm{I} \mathrm{ml} \mathrm{of} \mathrm{a}$ metal salt solution ( $50 \times$ required final concentration). The effect of carbonyl cyanide m-chlorophenylhydrazone (CCCP), an uncoupler of oxidative phosphorylation, on metal cation accumulation was determined after addition of the inhibitor (dissolved in $10 \mathrm{mM}$ $\mathrm{NaOH})$ to a cell suspension $5 \mathrm{~min}$ before glucose addition. Samples $(2 \mathrm{ml})$ were taken at intervals after adding the metal salt and filtered through $0.6 \mu \mathrm{m}$ pore size, $25 \mathrm{~mm}$ diam. membrane filters (Sartorius). Filters were washed immediately with $5 \mathrm{ml}$ PIPES buffer, then transferred to $5 \mathrm{ml}$ centrifuge tubes.

Metal analyses. To each centrifuge tube containing a filter and cells, $0.2 \mathrm{ml} 6 \mathrm{M}-\mathrm{HNO}_{3}$ was added, and the tubes were placed in a boiling water bath for $30 \mathrm{~min}$ to release cellassociated metal ions. Samples were made up to $4 \mathrm{ml}$ with distilled water, centrifuged to remove any undigested material, and the supernatant fluids were analysed for the appropriate elements by atomic absorption spectrophotometry using a Rank-Hilger Atomspek HII 70 and the standard procedures prescribed in the instrument's manual and data book (RankHilger, Margate, Kent). Quantities of accumulated cations (e.g. cell $\mathrm{Co}^{2+}$ ) and residual cations (e.g. cell $\mathrm{Mg}^{2+}$ ) are expressed throughout this paper as $\mathrm{nmol}$ (mg dry wt equiv.) ${ }^{-1}$, and the actual cell dry wt $\mathrm{ml}^{-1}$ in the suspension is indicated for each experim ent.

\section{RESULTS}

\section{Nature of $\mathrm{Co}^{2+}$ and $\mathrm{Cd}^{2+}$ accumulation}

Small amounts of $\mathrm{Co}^{2+}$ or $\mathrm{Cd}^{2+}$ were bound instantaneously on addition of the metal sulphates to $S$. cerevisiae. This apparent surface binding was independent of temperature ( 5 to $25^{\circ} \mathrm{C}$ ), the availability of an energy-yielding substrate or the presence of an energy- 

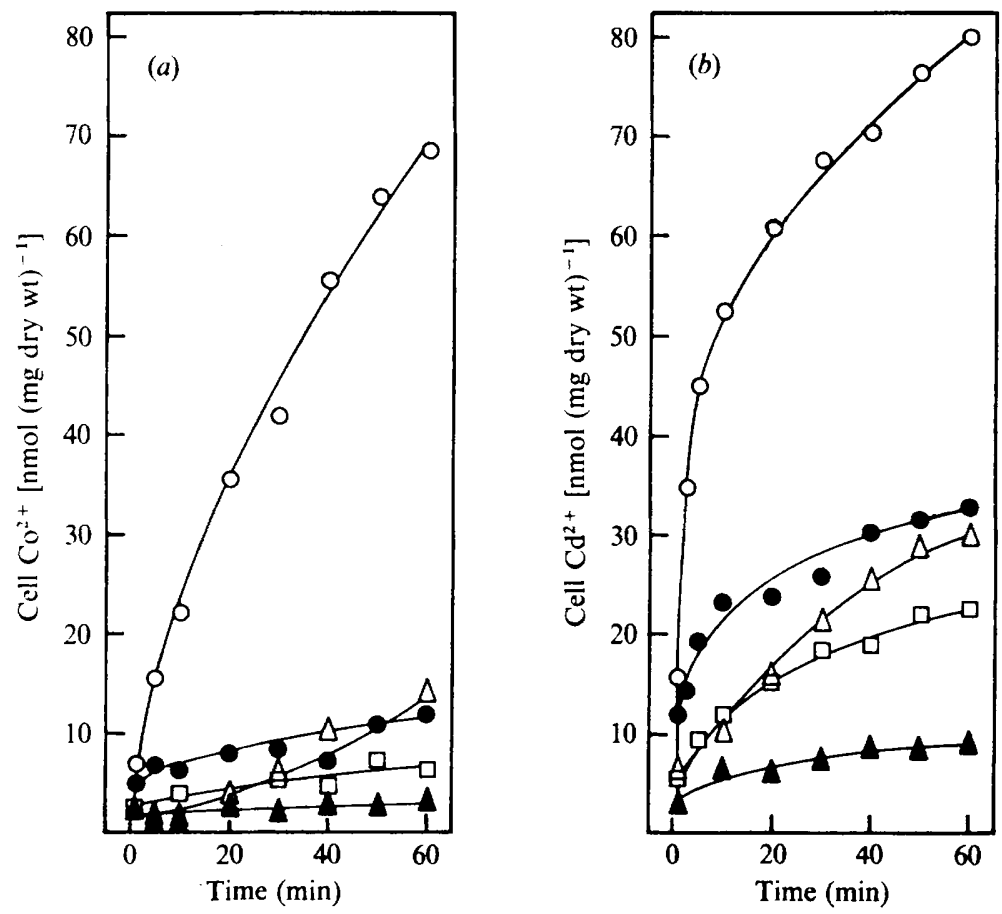

Fig. I. $\mathrm{Co}^{2+}$ and $\mathrm{Cd}^{2+}$ accumulation by $S$. cerevisiae $\left(0.4 \mathrm{Img}\right.$ dry wt $\left.\mathrm{ml}^{-1}\right)$ from (a) $0.2 \mathrm{~mm}-\mathrm{CoSO}_{4}$

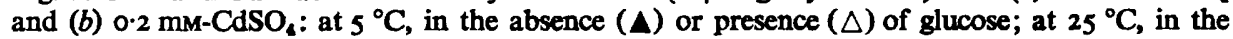
absence $(\square)$ or presence $(O)$ of glucose, or in the presence of glucose and $0.1 \mathrm{mM}-\mathrm{CCCP}(O)$.

coupling inhibitor (Fig. I). The surface-binding capacity of $S$. cerevisiae for divalent cations was relatively low by comparison, on an equal cell dry weight basis, with binding capacities of a range of algae, bacteria and filamentous fungi (Norris, 1976). The quantities of surface-bound $\mathrm{Co}^{2+}$ and $\mathrm{Cd}^{2+}$ were exceeded by the amounts of each cation subsequently accumulated at $25^{\circ} \mathrm{C}$ in the presence of glucose by a process of progressive cation uptake which was energy-dependent and depressed by low temperature, CCCP or the absence of glucose (Fig. I). 2-Deoxy-D-glucose is accumulated and phosphorylated but is not an energy source for S. cerevisiae (Van Steveninck, I968). Addition of 2-deoxy-D-glucose instead of glucose in the present experiments did not support cation uptake. Optimum temperatures for uptake of $\mathrm{Co}^{2+}$ and $\mathrm{Cd}^{2+}$ were between 25 and $30 .{ }^{\circ} \mathrm{C}$. A longer period of pre-incubation of the cells in buffer before adding glucose and cation resulted in lower rates of uptake. The initial rate of $\mathrm{Co}^{2+}$ uptake was reduced by $35 \%$ when glucose and $\mathrm{CoSO}_{4}$ additions were delayed until $6 \mathrm{~h}$ after preparation of the cell suspension while viability of the cells did not fall during the pre-incubation period (data not shown).

The cell $\mathrm{Mg}^{2+}$ concentration was not affected by the accumulation of $\mathrm{Co}^{2+}$ and $\mathrm{Cd}^{2+}$ (Fig. 2). The release of $74 \mathrm{nmol} \mathrm{K}^{+}(\mathrm{mg} \text { dry wt) })^{-1}$ during uptake of $36 \mathrm{nmol} \mathrm{Co}^{2+}(\mathrm{mg}$ dry wt) ${ }^{-1}$ (Fig. $2 a$ ) confirmed the previously described efflux of two $\mathrm{K}^{+}$ions for each $\mathrm{Co}^{2+}$ ion accumulated by yeast (Fuhrmann \& Rothstein, 1968). However, the lack of such exchange by $\mathrm{K}^{+}$-deficient cells, and during the later stages of prolonged $\mathrm{Co}^{2+}$ uptake (continuing for over $3 \mathrm{~h}$ after $\mathrm{CoSO}_{4}$ addition), showed that $\mathrm{K}^{+}$loss is not always a feature of $\mathrm{Co}^{2+}$ accumulation (Norris, 1976). Addition of $\mathrm{Cd}^{2+}$ resulted in a rapid release of approximately $66 \%$ of the cell $\mathrm{K}^{+}$(Fig. $2 b$ ); but no simple stoicheiometric relationship of $\mathrm{Cd}^{2+}$ 

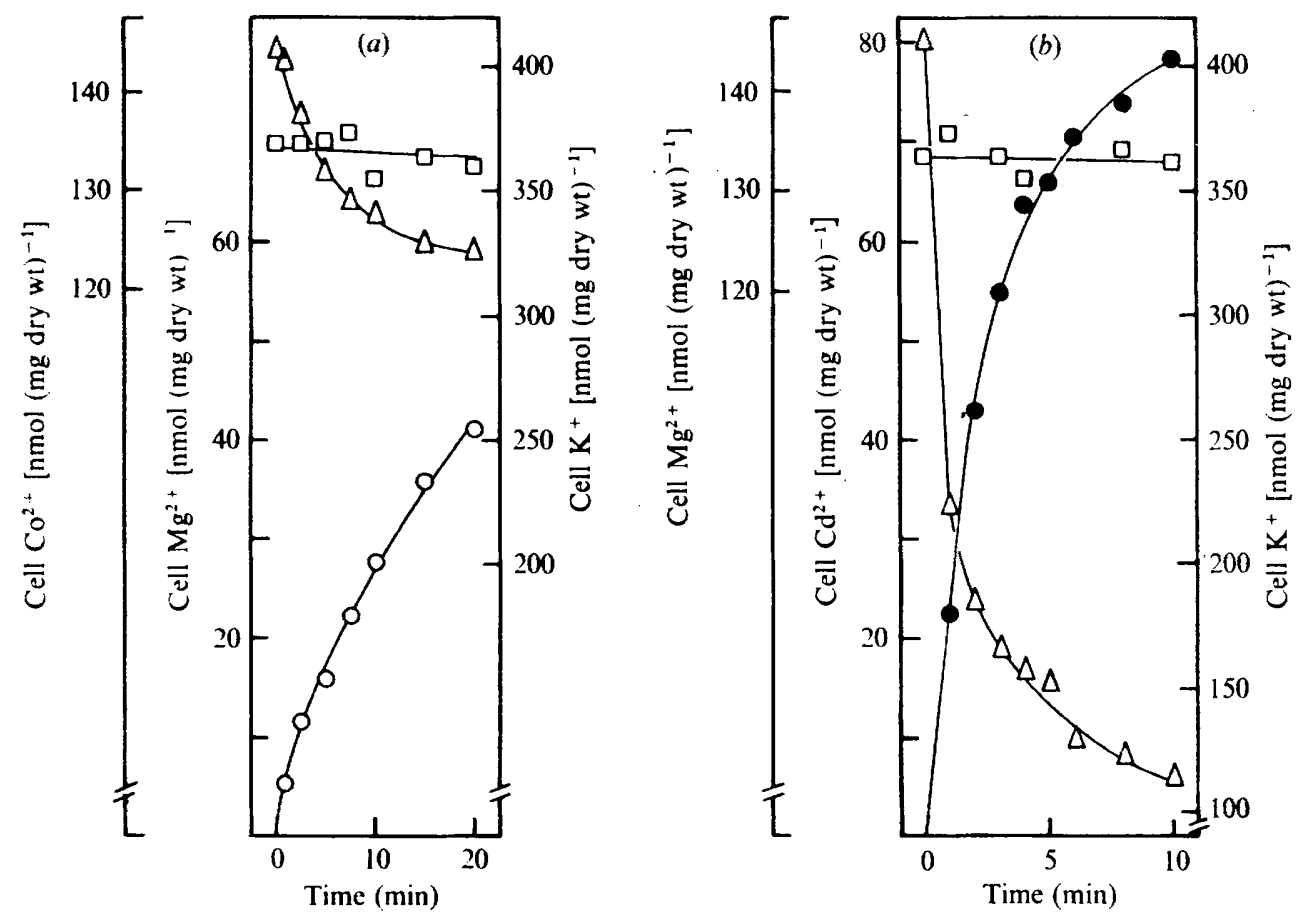

Fig. 2. Effect of $\mathrm{Co}^{2+}$ and $\mathrm{Cd}^{2+}$ accumulation on the $\mathrm{Mg}^{2+}$ and $\mathrm{K}^{+}$concentrations in $S$. cerevisiae at $25^{\circ} \mathrm{C}$ : $(a)$ cells $\left(0.39 \mathrm{mg}\right.$ dry wt ml $\left.{ }^{-1}\right)$ received glucose and $0.2 \mathrm{~mm}-\mathrm{CoSO}_{4} ;($ b) cells $(0.42 \mathrm{mg}$ dry wt $\mathrm{ml}^{-1}$ ) received glucose and $0.2 \mathrm{mM}-\mathrm{CdSO}_{4} \cdot \mathrm{Co}^{2+}(O), \mathrm{Cd}^{2+}(0), \mathbf{M g}^{2+}(\square), \mathrm{K}^{+}(\triangle)$.

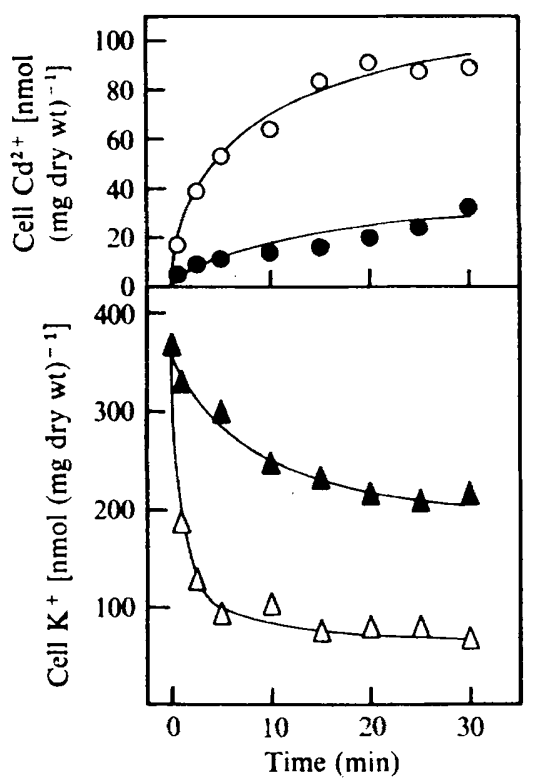

Fig. 3. Effect of $\mathrm{Ca}^{2+}$ on $\mathrm{Cd}^{2+}$ accumulation and subsequent $\mathrm{K}^{+}$release by $S$. cerevisiae $(0.38 \mathrm{mg}$ dry wt $\mathrm{ml}^{-1}$ ) at $25^{\circ} \mathrm{C}$ after glucose addition: $\mathrm{Cd}^{2+}$ accumulation from $0.2 \mathrm{mM}^{-C_{d S O}}{ }_{4}(O)$ or from $0.2 \mathrm{~mm}-\mathrm{CdSO}_{4}$ plus $0.2 \mathrm{~mm}-\mathrm{CaSO}_{4}(\bullet) ; \mathrm{K}^{+}$release with $\mathrm{CdSO}_{4}(\triangle)$ or with $\mathrm{CdSO}_{4}$ plus $\mathrm{CaSO}_{4}(\Delta)$. 
Table I. Effect of various metal salts on the cell $K^{+}$concentration of $S$. cerevisiae Metal salts (all sulphates except $\mathrm{HgCl}_{2}, \mathrm{~Pb}\left(\mathrm{NO}_{2}\right)_{2}$ and $\mathrm{AgNO}_{2}$ ) were added (to $0.2 \mathrm{mM}$ ) to $S$.cerevisiae $\left(0.36 \mathrm{mg}\right.$ dry wt $\mathrm{ml}^{-1}$ in PIPES buffer) at $25^{\circ} \mathrm{C}$; glucose was not added. Samples were taken $5 \mathrm{~min}$ after metal salt additions.

Metal cations

No addition

$\mathrm{Cd}^{2+}$

$\mathrm{Cd}^{2+}+\mathrm{Ca}^{2+}$

$\mathrm{Cd}^{3+}+\mathrm{Zn}^{2+}$

$\mathrm{Co}^{2+}$

$\mathrm{Pb}^{2+}$

$\mathrm{Hg}^{2+}$

$\mathrm{Cu}^{3+}$

$\mathrm{Ag}^{+}$

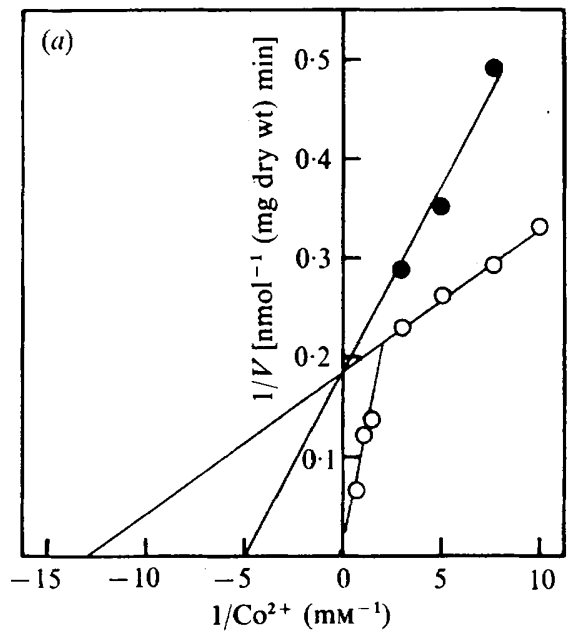

Cell K+ [nmol (mg dry wt) $)^{-1}$ ]

$$
\begin{aligned}
& 450 \\
& 339 \\
& 394 \\
& 319 \\
& 428 \\
& 442 \\
& 356 \\
& 122 \\
& 111
\end{aligned}
$$

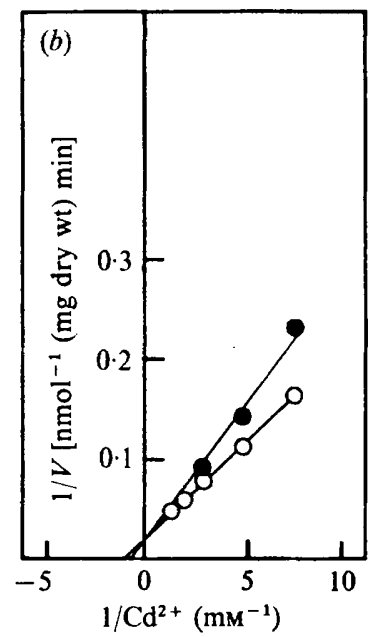

Fig. 4. Lineweaver-Burk plots of $\mathrm{Co}^{2+}$ and $\mathrm{Cd}^{2+}$ uptake. (a) $\mathrm{Co}^{2+}$ uptake after glucose addition at $25^{\circ} \mathrm{C}$ by $S$. cerevisiae $\left(0.40 \mathrm{mg}^{2}\right.$ ry wt $\left.\mathrm{ml}^{-1}\right)$ from solutions of CoSO, $(\mathrm{O})$ or CoSO, plus $0.2 \mathrm{~mm}$ $\mathrm{MgSO}_{4}(\bullet)$. (b) $\mathrm{Cd}^{2+}$ uptake after glucose addition at $25^{\circ} \mathrm{C}$ by S. cerevisiae $\left(0.42 \mathrm{mg} \mathrm{dry} \mathrm{wt} \mathrm{ml}{ }^{-1}\right)$ from solutions of $\mathrm{CdSO}_{4}(\mathrm{O})$ or $\mathrm{CdSO}_{4}$ plus $0.2 \mathrm{mM}^{-\mathrm{MgSO}_{4}}(\mathbf{O})$. All data points are means of four experiments.

uptake to $\mathrm{K}^{+}$loss was apparent. The ability of various cations to effect $\mathrm{K}^{+}$release was measured (Table $\mathrm{I}$ ). $\mathrm{Cu}^{2+}$ and $\mathrm{Ag}^{+}$caused immediate flocculation of cells and the most extensive $\mathrm{K}^{+}$release. $\mathrm{Cd}^{2+}$ and $\mathrm{Hg}^{2+}$ were equally effective. $\mathrm{Cd}^{2+}$-induced $\mathrm{K}^{+}$release was not affected by $\mathrm{Zn}^{2+}$ but was reduced by $\mathrm{Ca}^{2+}$ (Table I; Fig. 3). Less $\mathrm{K}^{+}$was released in the absence of glucose (Table 1 ) than after glucose addition (Figs $2 b$ and 3 ). When a cell suspension was pre-incubated and aerated for $6 \mathrm{~h}$ before $\mathrm{Cd}^{2+}$ addition, thus presumably exhausting endogenous energy-yielding substrates, there was little $\mathrm{Cd}^{2+}$ accumulation and a concurrent reduction in $\mathrm{K}^{+}$release (data not shown).

\section{Kinetics of $\mathrm{Co}^{2+}$ and $\mathrm{Cd}^{2+}$ uptake}

A double reciprocal plot (after Lineweaver \& Burk, 1934) of the initial rates of $\mathrm{Co}^{2+}$ uptake at $25^{\circ} \mathrm{C}$ against a range of $\mathrm{Co}^{2+}$ concentrations indicated two apparent affinity

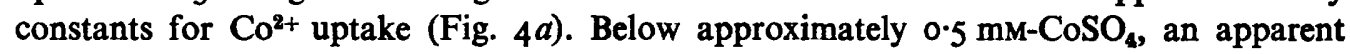
$K_{\mathrm{m}}$ of $77 \mu \mathrm{M}$ and a $V_{\max }$ of $5 \cdot 4 \mathrm{nmol} \mathrm{Co}^{2+}(\mathrm{mg} \text { dry wt) })^{-1} \mathrm{~min}^{-1}$ were observed. $\mathrm{Mg}^{2+}$ was a 
Table 2. Mutual inhibition of the initial rates of metal cation uptake by $S$. cerevisiae from mixed solutions of $\mathrm{CoSO}_{4}$ with other metal sulphates

Metal sulphates were added (to $0.2 \mathrm{~mm})$ after glucose addition to $S$. cerevisiae $(0.43 \mathrm{mg}$ dry wt $\mathrm{ml}^{-1}$ in PIPES buffer) at $25^{\circ} \mathrm{C}$. Inhibition of the uptake of $\mathrm{Co}^{8+}$ or other metal cation is expressed as a percentage of the uptake of each cation from its respective single metal sulphate $(0.2 \mathrm{~mm})$ solution.

Metal cations added

$$
\begin{aligned}
& \mathrm{Co}^{2+}+\mathrm{Mn}^{2+} \\
& \mathrm{Co}^{2+}+\mathrm{Cd}^{2+} \\
& \mathrm{Co}^{2+}+\mathrm{Ni}^{2+} \\
& \mathrm{Co}^{2+}+\mathrm{Zn}^{2+}
\end{aligned}
$$

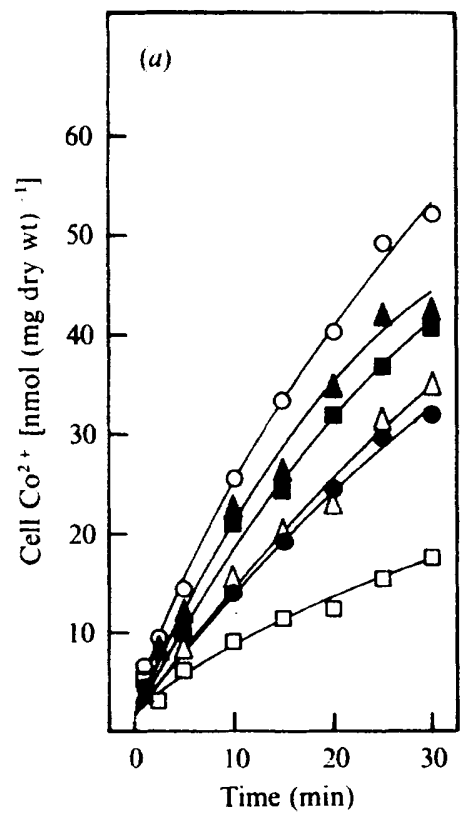

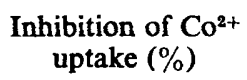
uptake $(\%)$

$\begin{array}{rr}30 & 61 \\ 25 & 5 \\ 49 & 43 \\ 73 & 14\end{array}$

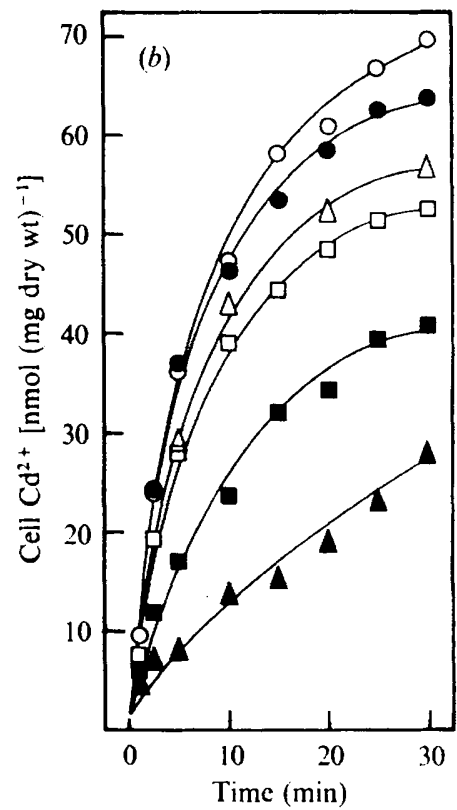

Fig. 5. Effect of divalent cations on accumulation of $\mathrm{Co}^{2+}$ and $\mathrm{Cd}^{2+}$ by $\mathrm{S}$. cerevisiae $(0.43 \mathrm{mg}$ dry wt $\mathrm{ml}^{-1}$ ) at $25^{\circ} \mathrm{C}$ after addition of glucose and (a) $0.2 \mathrm{~mm}^{-C_{0 S O}}(\mathrm{O})$ or $(b) 0.2 \mathrm{~mm}-\mathrm{CdSO}_{4}(\mathrm{O})$, with with $0.2 \mathrm{mM}$ sulphates of $\mathrm{Mg}^{2+}(\triangle), \mathrm{Ni}^{2+}(O), \mathrm{Mn}^{2+}(\square), \mathrm{Zn}^{2+}(\square)$ and $\mathrm{Ca}^{2+}(\Delta)$.

competitive inhibitor of this uptake with an apparent $K_{1}$ of $125 \mu \mathrm{M}$. Above approximately $0.5 \mathrm{mM}^{-\mathrm{CoSO}_{4}}$, a sharp reduction of affinity and an increase in the rate of $\mathrm{Co}^{2+}$ uptake occurred with an apparent $K_{\mathrm{m}}$ greater than $0 . \mathrm{I} \mathrm{M}$ and a $V_{\max }$ of approximately $200 \mathrm{nmol}$ $\mathrm{Co}^{2+}(\mathrm{mg} \mathrm{dry} \mathrm{wt})^{-1} \mathrm{~min}^{-1}$. The apparently 'biphasic' kinetic nature of $\mathrm{Co}^{2+}$ uptake resembles that shown for monovalent thallium uptake by $S$. cerevisiae (Norris et al., 1976). However, the results cannot indicate whether the different affinities for $\mathrm{Co}^{2+}$ uptake reflect a change in the translocation process of a single uptake system or utilization of different uptake systems. Furthermore, cation concentration-dependent changes of the membrane surface potential can give an appearance of multiphasic uptake systems with Lineweaver-Burk plots of such data (Theuvenet \& Borst-Pauwels, 1976).

$\mathrm{Cd}^{2+}$ uptake at $25^{\circ} \mathrm{C}$ showed an apparent $K_{\mathrm{m}}$ of I mM and $V_{\max }$ of $50 \mathrm{nmol} \mathrm{Cd} \mathrm{Cd}^{2+}(\mathrm{mg}$ dry wt) ${ }^{-1} \mathrm{~min}^{-1}$. $\mathrm{Mg}^{2+}$ was a less effective competitive inhibitor of $\mathrm{Cd}^{2+}$ uptake than of $\mathrm{Co}^{2+}$ uptake with an apparent $K_{1}$ of $\mathrm{I} \cdot 4 \mathrm{mM}$ (Fig. 4 b). 


\section{Specificity of $\mathrm{Co}^{2+}$ and $\mathrm{Cd}^{2+}$ uptake}

The competitive inhibition of $\mathrm{Co}^{2+}$ uptake by $\mathrm{Mg}^{2+}$ and inhibition of $\mathrm{Cd}^{2+}$ uptake by $\mathrm{Ca}^{2+}$ (Fig. 3) were compared with inhibition of $\mathrm{Co}^{2+}$ and $\mathrm{Cd}^{2+}$ uptake by other cations (Fig. 5). The amount of divalent cation accumulated was similar during the simultaneous uptake of $\mathrm{Co}^{2+}$ and $\mathrm{Mn}^{2+}$ or $\mathrm{Co}^{2+}$ and $\mathrm{Zn}^{2+}$, with weak inhibition of $\mathrm{Co}^{2+}$ uptake by $\mathrm{Mn}^{2+}$ complemented by strong inhibition of $\mathrm{Mn}^{2+}$ uptake by $\mathrm{Co}^{2+}$, and strong inhibition of $\mathrm{Co}^{2+}$ uptake by $\mathrm{Zn}^{2+}$ complemented by weak inhibition of $\mathrm{Zn}^{2+}$ uptake by $\mathrm{Co}^{2+}$ (Table 2). Mutual inhibition of $\mathrm{Ni}^{2+}$ and $\mathrm{Co}^{2+}$ uptake from mixtures was generally equivalent for each cation. The uptake rates of $\mathrm{Ni}^{2+}, \mathrm{Mn}^{2+}$ and $\mathrm{Zn}^{2+}$ in the absence of $\mathrm{Co}^{2+}$ were similar to the uptake rate of $\mathrm{Co}^{2+}$ in the absence of other divalent cations (data not shown). No $\mathrm{Ca}^{2+}$ uptake was detected from $0.2 \mathrm{mM}$ or I mM CaSO${ }_{4}$ or $\mathrm{Ca}\left(\mathrm{NO}_{3}\right)_{2}$ in the absence or presence of $\mathrm{Co}^{2+}$. Thus inhibition of $\mathrm{Co}^{2+}$ uptake decreased down the following series [crystal ionic radii of the cations, in $\mathrm{nm}$, (after Pauling, 1960) are given in parentheses]:

$\mathrm{Zn}^{2+}(0.074)>\mathrm{Ni}^{2+}(0.072)>\mathrm{Mg}^{2+}(0.065)>\mathrm{Mn}^{2+}(0.080)>\mathrm{Cd}^{2+}(0.097)>\mathrm{Ca}^{2+}(0.099)$. Inhibition of $\mathrm{Co}^{2+}$ uptake was most severe by cations of similar size to $\mathrm{Co}^{2+}(0.074 \mathrm{~nm})$.

Inhibition of $\mathrm{Cd}^{2+}$ uptake by other divalent cations also appeared to be related to the ionic radii of the cations involved. The initial rate of $\mathrm{Cd}^{2+}(0.097 \mathrm{~nm})$ uptake was strongly depressed by $\mathrm{Ca}^{2+}(0.099 \mathrm{~nm})$ and less strongly by $\mathrm{Mn}^{2+}(0.080 \mathrm{~nm})$, with the smaller metal cations having little effect at concentrations equimolar with $\mathrm{Cd}^{2+}($ Fig. 5 b). Uptake of $\mathrm{Mn}^{2+}$ was strongly inhibited by $\mathrm{Cd}^{2+}$, which had little effect on the uptake of $\mathrm{Zn}^{2+}$ or $\mathrm{Ni}^{2+}$.

Addition of $\mathrm{K}^{+}$or $\mathrm{Na}^{+}$(as sulphates) at concentrations equimolar with $\mathrm{Co}^{2+}$ or $\mathrm{Cd}^{2+}$ caused only slight inhibition of the rates of divalent cation uptake. Release of cell $\mathrm{K}^{+}$after $\mathrm{Cd}^{2+}$ addition was unaffected by the presence of the monovalent cations. The lack of effective inhibition of $\mathrm{Cd}^{2+}$ uptake by $\mathrm{Na}^{+}(0.095 \mathrm{~nm})$ indicated that cations would need to have a similar charge before the criterion of ionic radius could determine competition for uptake.

\section{DISCUSSION}

Preclusion of extensive loss of cation uptake activity by the use of cells soon after harvesting from growing cultures resulted in greater accumulation of metal cations than seen in earlier studies which used starved yeast from commercial sources (Fuhrmann \& Rothstein, I968; Ponta \& Broda, 1970).

The competition for uptake between $\mathrm{Co}^{2+}$ and $\mathrm{Ni}^{2+}, \mathrm{Zn}^{2+}$ or $\mathrm{Mn}^{2+}$ suggested that these cations shared a cation uptake system of low specificity, as proposed earlier by Fuhrmann \& Rothstein (1968). Mutual inhibition of $\mathrm{Mn}^{2+}$ and $\mathrm{Cd}^{2+}$ uptake suggested that $\mathrm{Cd}^{2+}$ was also accumulated by this system. Cadmium exhibited some cell-metal cation interactions not shared by the other cations, such as (i) the relatively slight inhibition of $\mathrm{Cd}^{2+}$ uptake by equimolar concentrations of smaller divalent cations, despite the apparently higher affinity for $\mathrm{Co}^{2+}$ than for $\mathrm{Cd}^{2+}$ uptake; and (ii) the $\mathrm{Cd}^{2+}$-induced $\mathrm{K}^{+}$release. The $\mathrm{Cd}^{2+}$-induced $\mathrm{K}^{+}$ loss resembled that observed previously with $S$. cerevisiae in the presence of $\mathrm{Hg}^{2+}$; the latter was attributed (Passow \& Rothstein, 1960) to cell membrane disruption after metal cation-membrane sulphydryl group interactions. Sulphydryl groups are generally the preferred binding sites of $\mathrm{Cd}^{2+}$ and $\mathrm{Hg}^{2+}$ (Vallee \& Ulmer, ${ }^{972}$ ), and $\mathrm{Ag}^{+}$, which promoted the most extensive $\mathrm{K}^{+}$release in the present experiments, forms strong complexes only with cysteine of all the amino acids (Gruen, 1975 ). $\mathrm{Cd}^{2+}$-induced $\mathrm{K}^{+}$loss in the present experiments appeared to depend on some $\mathrm{Cd}^{2+}$ uptake. Either starving the cells of energyyielding substrates, or addition of $\mathrm{Ca}^{2+}$, depressed $\mathrm{Cd}^{2+}$ uptake and subsequent $\mathrm{K}^{+}$loss 
although probably neither treatment would have affected $\mathrm{Cd}^{2+}$ binding to membranesurface sulphydryl groups. The $\mathrm{K}^{+}$loss thus appears similar to that seen with metal cationinduced passive permeability of mitochondrial membranes where, with 'energized' membrane conditions, some entry of $\mathrm{Cu}^{2+}$ into regions not accessible in a 'resting' membrane was required for extensive deformation of the membrane (Hwang, Scott \& Brierley, 1972). The presence of $\mathrm{Hg}^{2+}$ in yeast cytoplasm after addition of $\mathrm{HgCl}_{2}$ to cells (Murray \& $\mathrm{Kidby}$, 1975) has shown that $\mathrm{Hg}^{2+}$ uptake may occur and, as with $\mathrm{Cd}^{2+}, \mathrm{Hg}^{2+}$ uptake might have occurred before the $\mathrm{K}^{+}$release observed after $\mathrm{HgCl}_{2}$ addition.

The non-physiological concentrations of the metal cations used, leading to their gratuitous accumulation, should be emphasized. $\mathrm{Cd}^{2+}$ inhibition of $\mathrm{Zn}^{2+}$ uptake from $\mathrm{I} \cdot \mathrm{I} \mu \mathrm{M}-\mathrm{ZnCl}_{2}$ by Candida utilis (Failla et al., 1976) suggests that the essentially homologous chemistry of the elements and their compounds, rather than similarities of cation size, may be important in competition for metal cation uptake by yeasts from lower metal concentration ranges than used in the present study.

We thank Dr J. A. Taylor for discussion. This work was supported by the Science Research Council and Imperial Chemical Industries Ltd.

\section{REFERENCES}

Failla, M. L., Benedict, C. D. \& Weinberg, E. D. (i976). Accumulation and storage of $\mathrm{Zn}^{2+}$ by Candida utilis. Journal of General Microbiology 94, 23-36.

Futrmann, G. F. \& Rothsteln, A. (1968). The transport of $\mathrm{Zn}^{2+}, \mathrm{Co}^{2+}$ and $\mathrm{Ni}^{2+}$ into yeast cells. Biochimica et biophysica acta $\mathrm{I63}, 325-330$.

Fuhrmann, G. F., Wehrl, E. \& Boehm, C. (1974). Preparation and identification of yeast plasma membrane vesicles. Biochimica et biophysica acta 363, 295-310.

Good, N. E., Winget, G., Winter, W., Connolly, T. N., IzaWa, S. \& Singh, R. M. M. (1966). Hydrogen ion buffers for biological research. Biochemistry $5,467-477$.

GruEN, L. C. (1975). Interaction of amino acids with silver(I) ions. Biochimica et biophysica acta $3^{86}$, 270-274.

Hwang, K. M., Scott, K. M. \& Brierley, G. P. (1972). Ion transport by heart mitochondria. The effects of $\mathrm{Cu}^{2+}$ on membrane permeability. Archives of Biochemistry and Biophysics $\mathbf{1 5 0}, 746-756$.

Lineweaver, H. \& BURK, D. (1934). The determination of enzyme dissociation constants. Journal of the American Chemical Society 56, 658-666.

MurRAY, A. D. \& KIDBY, D. K. (1975). Sub-cellular location of mercury in yeast grown in the presence of mercuric chloride. Journal of General Microbiology 86, 66-74.

Nusson, R. (1970). Aspects of the toxicity of cadmium and its compounds. Ecological Research Committee Bulletin No. 7, Swedish Natural Science Research Council.

NordberG, G. F. (1974). Health hazards of environmental cadmium pollution. Ambio 3, 55-66.

NoRris, P. R. (1976). Accumulation of metals by microorganisms. Ph.D. thesis, University of London.

Norris, P. R., MaN, W. K., Hughes, M. N. \& Kelly, D. P. (1976). Toxicity and accumulation of thallium in bacteria and yeast. Archives of Microbiology 110, 279-286.

Passow, H. \& Rothstein, A. (1960). The binding of mercury by the yeast cell in relation to changes in permeability. Journal of General Physiology 43, 621-633.

Pauling, L. (1960). The Nature of the Chemical Bond and the Structure of Molecules and Crystals. New York: Cornell University Press.

PoNTA, H. \& BRODA, E. (1970). Mechanismen der Aufnahme von Zink durch Bäckerhefe. Planta 95, 18-26.

Ross, I.S. (1975). Some effects of heavy metals on fungal cells. Transactions of the British Mycological Society 64, 175-193.

RotesteIn, A. \& HaYes, A. D. (1956). The relationship of the cell surface to metabolism. XIII. The cation binding properties of the yeast cell surface. Archives of Biochemistry and Biophysics 63, 87-99.

Rothistein, A., HAYes, A. D., Jennings, D. H. \& HoPPER, D. C. (I958). The active transport of $\mathrm{Mg}^{2+}$ and $\mathrm{Mn}^{2+}$ into the yeast cell. Journal of General Physiology 41, 585-594.

Theuvenet, A. P. R. \& Borst-Pauwels, G. W. F. H. (1976). The influence of surface charge on the kinetics of ion-translocation across biological membranes. Journal of Theoretical Biology 57, 313-329.

VALLEE, B. L. \& Ulmer, D. D. (1972). Biochemical effects of mercury, cadmium, and lead. Annual Review of Biochemistry 4r, 91-128.

VAN STEVENINCK, J. (1968). Transport and transport-associated phosphorylation of 2-deoxy-D-glucose in yeast. Biochimica et biophysica acta 163, 386-394. 